\title{
EFFECT OF GLYPHOSATE ON DODDER (Cuscuta $s$ ) WEED GROWING WITH CLOVER (Trifolium alexandrinum L).
}

Salim Hammadi Antar

Field Crops Dept-Agric \& Forestry College

Mosul Univ Iraq

\begin{abstract}
The experiment was conducted during the Agricultural season 2008 in the green house of Field crops .Dept, College of Agriculture and forestry. The effect of different dosses of glyphosate (48, $96,144,192 \mathrm{ml} / \mathrm{ha}$ ) with different durations time of herbicide application after (10,20,30days) of plant clover infestation were studied . Dodder can competes strongly with clover, potentially reducing clover growth . Fresh and dry weights of dodder were decreased at the first and second durations of herbicide application. The height of plant $\&$ no . of beanches were significantly higher at the first duration whears the dry weight of stems, leaves and roots were significantly decreased as the time of application increased. On the other hand, fresh and dry weights of dodder plants were reduced as the doses of herbicide increased. Clover plant height and no . of branches were increased as the glyphosate doses increased .Dry weights of leaves, stems and roots were inversely related to the dose of glyphosate Fresh and dry weights of dodder were negatively related to the dose of herbicide at all durations of herbicide application . The results of the present study showed that glyphosate caused a cleare damage on dodder plants where as clover plants did not obtain any sign of damage had less effect on it .
\end{abstract}

\section{Introduction}

Clover (Trifolium alexandrinum L) is an important leguminous Forage crop used for cattel food. It coud be used for feeding in different ways. It is widely suppressed by weed infestation especially with parasitic weeds . In Iraq,dodders ( Cuscuta $s p$ ) considerd as a serious parasitic flowering plants (Altekretee et al 1981). Dodder seeds has the ability to remain viable for many years ( Karapetyan 1972 , Ashton 1976). Maddah, 1976 showed that about $94 \%$ of the seedling emerged during a period of 3 weeks from 4 to 25 April. In Morocco, it was found that the decrease of crop yields was due to the presence of dodder plant which were estimated from 20 to $50 \%$ ( Saffour 1999). Similar results were also recorded in Algeria with yield crops losses range from 5-100 \% . In Iraq, until now there is no clear stratege in the control of dodder weed. Only an old or traditional method are usualy used by the Iraqi farmers such as solarization, herbicides, resistant varieties , trap and catch crops or cultural methods (sowing delayed, distance between plants...etc). Burning are usually used in the case of heavy infestation Norris 1973 . Chemicals are used successfully to control dodder plants in some border countries of Iraq (Abu-Irmaileh and Fucik ,1989).The lack of chemicals and their high costs increases the difficulties in the use of herbicide in the farm .It could be control dodder after it attached with clover by means of chemicals, but this sort of treatment my have a negative effect on clover forage. This was confimed through Rccieved 14/2/2011 accepted 12/9/2011. 
a research conducted in Egypt by Hacquet et al(1983) who reported that glyphosate at 75-150 g/ha and its analong sulfosate (touch-down) control dodder directly and through their systematic movement within the host phloem system : He added that glyphosate can be applied to clover after dodder cutting. Different doses and application of glyphosate used in Egyptian clover Abd-El-Hamid and shebl , (2000) , Hassanein and Ibrahim ,2000). The work described in this study is an attempt to through some light on the factors which govern the effect of time of application \& different doses of glyphosate on the behaviour of dodder weed when the plants growing together with foliage crop (Trifolium alexandrinum $\mathrm{L}$ ) .

\section{Materials and Methods}

On 28 September 2008 , 10 seeds of Egyptian clover (Trifolium alexandrinum) were sown at $1.5 \mathrm{~cm}$ deep in $40 \mathrm{~cm}$ diameter plastic pots filled with loamly soil in green house at the Field crops dept, College of Agric \& Forestry , Mosul Univ .A segments of dodder plants which infested clover crop after one week of emergence were selected. Glyphosate was applied post - emergence by hand sprayer at rates of $0.0,48,96,144,192 \mathrm{ml}$.a.i./ha in $300 \mathrm{~L}$ ha- 1 of water, with different duration time of applications ( after 10 , 20,30 day of plants crop in infestion ). Watering was done by overhead irrigation using a watering can with a fin rose. The experiment was laid out as a completely randomzed design with three replicates arrarged on a bench in the green house . At harvest , 60 days after plant infestion, fresh and dry weights of dodder plants were estimated per pot . Moreover crop branch numbers, plant height and dry weights of leaves, stems and roots of three plants per pot were measured. Data were subjected to analysis of variance using the SAS satatistical package . comparison between treatment means was done by Duncans Multiple Range Test.

\section{Results and discussion}

Effect of duration time of glyphosate application : Table (1) showes that durations of time application had a high significant effect on dodder fresh weight . The fresh weight of dodder plants infested 30 days after sprying was significantly higher than those treated 10 or 20 days durations. The herbicide reductions were 0.112 an $0.071 \mathrm{~g}$ for 10and 20 days duration of application respectively. The reason for this reduction may be attributed to the fact that a high tempreture enhanced the effect of herbicide on the plants espically where the plants were still young at the first duration of application .The opposite trend was obtained from the same table for dry weight of stems, leaves and roots where the values were significant weight when the plantd treated of days after spraying as compared with those infested 20 or 30 days after treatment. This results are in agreement with those of Dawson and Saghir . (1983) who found that the duration time of herbicide application was more effective on the control of dodder particularrly 20 days after infestion on dodder . Hight of clover plants did not affected in the $1^{\text {st }}$ duration as compared with the $3^{\text {rd }}$ duration wheras the hight of plants in the $1^{\text {st }}$ duration significantly were higher with average of $2.39 \mathrm{~cm}$ compared with the second duration .Number of branches at the $1^{\text {st }}$ duration were significantly higher with average of 0.14 and 0.17 as compared with the $2^{\text {nd }}$ and $3^{\text {rd }}$ duration respectively. Similar results were obtained for Number 
of branches at the first duration which had a significantly higher values as compared for those found at the second and third durations time of herbicide application.It seems likely that when herbicide applied after 10 days of duration the effect was more obvious on the clover plants than dodder, but as the application herbicide delyed for 10-30 days of duration, the clover plants did not show any serious effect .

Effect of glyphosate rates:Table (2) shows that using glyphosate herbicide at different doses were significantly affected the characteristic of dodder plants infested with clover crops . The fresh and dry weights of survival dodder plants were inversely related to the dose of herbicide. The higher the dose of herbicide used the more damage of dodder plants occurred .These results were fully supported by Fer (1983) who reported that using glyphosate high dose was more effect on dodder live plants.Plant height and branch numbers of clover plants were significantly redused as the dose of herbicide increased but this reduction did not reach to the level of significant effect when using the herbicide at dose of $(921 \mathrm{ml})$. On the other hand there was a tendency that plant height increased with increasing herbicide doses.It seems likely that the effect of dodder on clover plants were reduced as the herbicide doses increased. The great reduction of clover plant height and no. of branches were only seen when using herbicide at doses of $(48,96,144,192)$. There is a clear evidence from table (2) that dry weights of leves, stems and roots increased as the doses of herbicide increased and the dry weights of all these characterstics were significantly redused as compared with the control treatment. .

Interaction effect of durations and herbicide doses : Table (3) shows that the interaction between doses of herbicide and the durations of time of application had a significant effect on all characters studied. The mortility of dodder plants was clearly obtained at the first duration wheras the dodder plants had a great apportunity to survive at the $2^{\text {nd }}$ and $3^{\text {rd }}$ duration times of application . The same results were reflected on the fresh weights of dodder plants. The reason for this may be due to the fact that the effect of herbicide dose caused a high damage on the dodder plants at the first duration of application as compared with any time of application. These results are in agree with those found by Moshalenko and Dement (1991) . The dry weights of dodder plants had follow the same pattern of fresh weight .The plant height of clover plants were significantly reduced with increasing the dose of herbicide but this interaction did not reach the significant effect especilly when using the dose (144 and 192) at the first duration of application and $192 \mathrm{ml}$ in the third duration as compared with untreated control plants. It can be concluded that increasing the dose of herbicide led to a great damage to the dodder plants and this gave a good opportunity to the clover plants to survive and produses new shoots and grow again with a good establishment. There was a clear evidence that herbicide had no effect on clover characters which had been studied .Moreover, it has been noted that dodder plants were more sensitivs to the dose of herbicide than of clover plant .No.of branches for plants survived when glyphosate applied at dose of $192 \mathrm{ml}$ at the $1^{\text {st }}$ duration were significantly higher as compared with all other treatment . 
Table (1) : Effect of durations time of glyphosate application on the characterties of dodder plants growing with clover crop..

\begin{tabular}{|c|c|c|c|c|c|c|c|}
\hline $\begin{array}{c}\text { Durations time of } \\
\text { application }\end{array}$ & $\begin{array}{c}\text { Freshweight } \\
\text { (dodder)g/plant }\end{array}$ & $\begin{array}{c}\text { Dry Weight } \\
\text { (dodder)g/plant }\end{array}$ & $\begin{array}{c}\text { Length of } \\
\text { plant cm }\end{array}$ & $\begin{array}{c}\text { Number of } \\
\text { branchs/plant }\end{array}$ & $\begin{array}{c}\text { Dry } \\
\text { weight(stems) } \\
\text { g/3plant }\end{array}$ & $\begin{array}{c}\text { Dry } \\
\text { weight(leaves) } \\
\mathrm{g} / 3 \text { plant }\end{array}$ & $\begin{array}{c}\text { Dry } \\
\text { weight(roots) } \\
\mathrm{g} / 3 \text { plant }\end{array}$ \\
\hline 10 & $\begin{array}{c}0.158 \\
\mathrm{~b}\end{array}$ & $\begin{array}{c}0.0448 \\
\mathrm{~b}\end{array}$ & $\begin{array}{c}30 \\
\mathrm{a}\end{array}$ & $1.43 \mathrm{a}$ & $0.943 \mathrm{a}$ & $0.751 \mathrm{a}$ \\
\hline 20 & $\begin{array}{c}0.199 \\
\mathrm{~b}\end{array}$ & $\begin{array}{c}0.472 \\
\mathrm{~b}\end{array}$ & $\begin{array}{c}27.61 \\
\mathrm{~b}\end{array}$ & $1.29 \mathrm{~b}$ & $0.876 \mathrm{~b}$ & $0.733 \mathrm{~b}$ & $0.717 \mathrm{~b}$ \\
\hline 30 & $\begin{array}{c}0.270 \\
\mathrm{a}\end{array}$ & $\begin{array}{c}0.0788 \\
\mathrm{a}\end{array}$ & $\begin{array}{c}29.39 \\
\mathrm{ab}\end{array}$ & $1.26 \mathrm{~b}$ & $0.816 \mathrm{c}$ & $0.703 \mathrm{c}$ & $0.727 \mathrm{~b}$ \\
\hline
\end{tabular}

Table (2) : Effect of glyphosate rates on the characterties of dodder plants growing with clover crop...

\begin{tabular}{|c|c|c|c|c|c|c|c|}
\hline $\begin{array}{l}\text { Doses of } \\
\text { herbicide }\end{array}$ & $\begin{array}{l}\text { Fresh weight } \\
\text { (dodder)g/plant }\end{array}$ & $\begin{array}{c}\text { Dry Weight } \\
\text { (dodder)g/plant }\end{array}$ & $\begin{array}{l}\text { Length } \\
\text { of plant } \\
\mathrm{cm}\end{array}$ & $\begin{array}{r}\text { Number } \\
\text { of } \\
\text { branchs/pl } \\
\text { ant }\end{array}$ & $\begin{array}{c}\text { Dry } \\
\text { weight(stems) } \\
\text { g/3plant }\end{array}$ & $\begin{array}{c}\text { Dry } \\
\text { weight(leaves) } \\
\text { g/3plant }\end{array}$ & $\begin{array}{c}\text { Dry } \\
\text { weight(roots) } \\
\text { g/3plant }\end{array}$ \\
\hline control & $\begin{array}{r}\text { Zero } \\
\mathrm{d}\end{array}$ & $\begin{array}{l}\text { Zero } \\
\mathrm{c}\end{array}$ & $\begin{array}{c}36.67 \\
\mathrm{a}\end{array}$ & $2.33 \mathrm{a}$ & $1.230 \mathrm{a}$ & $1.103 \mathrm{a}$ & $0.933 \mathrm{a}$ \\
\hline $\begin{array}{c}\text { Infection without } \\
\text { spray } \\
\end{array}$ & $\begin{array}{c}0.725 \\
\mathrm{a} \\
\end{array}$ & $\begin{array}{c}0.200 \\
\mathrm{a} \\
\end{array}$ & $\begin{array}{c}21.33 \\
\mathrm{~d}\end{array}$ & $1.23 \mathrm{~b}$ & $0.393 \mathrm{f}$ & $0.244 \mathrm{f}$ & $0.548 \mathrm{e}$ \\
\hline 48 & $\begin{array}{c}0.391 \\
b\end{array}$ & $\begin{array}{c}0.1130 \\
b\end{array}$ & $\begin{array}{c}24.00 \\
\mathrm{c} \mathrm{d}\end{array}$ & $1.06 \mathrm{c}$ & 0.589 e & $0.488 \mathrm{e}$ & $0.680 \mathrm{~d}$ \\
\hline 96 & $\begin{array}{c}0.093 \\
\mathrm{c}\end{array}$ & $\begin{array}{c}0.0190 \\
\mathrm{c}\end{array}$ & $\begin{array}{c}26.11 \\
c\end{array}$ & $1.00 \mathrm{c}$ & $0.802 \mathrm{~d}$ & $0.731 \mathrm{~d}$ & $0.747 \mathrm{c}$ \\
\hline 144 & $\begin{array}{c}0.039 \\
\mathrm{~cd}\end{array}$ & $\begin{array}{c}0.0065 \\
\mathrm{c}\end{array}$ & $\begin{array}{c}31.67 \\
b\end{array}$ & $1.00 \mathrm{c}$ & $0.988 \mathrm{c}$ & $0.884 \mathrm{c}$ & $0.688 \mathrm{~d}$ \\
\hline 192 & $\begin{array}{c}0.008 \\
\mathrm{~d}\end{array}$ & $\begin{array}{c}0.0027 \\
\mathrm{c}\end{array}$ & $\begin{array}{c}34.22 \\
a b\end{array}$ & $1.33 \mathrm{~b}$ & $1.159 \mathrm{~b}$ & $0.924 \mathrm{~b}$ & $0.808 \mathrm{~b}$ \\
\hline
\end{tabular}


Table (3) : The Intraction of durations and time herbicide doses on the characterties of dodder plants growing with clover crop..

\begin{tabular}{|c|c|c|c|c|c|c|c|c|}
\hline $\begin{array}{l}\text { Durations of } \\
\text { time }\end{array}$ & Doses of herbicide & $\begin{array}{l}\text { Fresh weight } \\
\text { (dodder)g/plant }\end{array}$ & $\begin{array}{c}\text { Dry Weight } \\
\text { (dodder)g/plant }\end{array}$ & $\begin{array}{l}\text { Length of } \\
\text { plant } \mathrm{cm}\end{array}$ & $\begin{array}{r}\text { Number of } \\
\text { branchs/pla } \\
\text { nt }\end{array}$ & $\begin{array}{c}\text { Dry weight(stems) } \\
\text { g/3plant }\end{array}$ & $\begin{array}{c}\text { Dry weight(leaves) } \\
\text { g/3plant }\end{array}$ & $\begin{array}{c}\text { Dry weight(roots) } \\
\text { g/3plant }\end{array}$ \\
\hline \multirow[t]{6}{*}{10} & control & Zero c & Zero c & $36.67 \mathrm{a}$ & $2.33 \mathrm{a}$ & $0.933 \mathrm{a}$ & $1.10 \mathrm{a}$ & $1.320 \mathrm{a}$ \\
\hline & Infection without spray & $0.725 \mathrm{a}$ & $0.22 \mathrm{a}$ & $20.00 \mathrm{f}$ & $1.23 \mathrm{c}$ & $0.573 \mathrm{e}$ & $0.267 \mathrm{i}$ & $0.450 \mathrm{k}$ \\
\hline & 48 & $0.108 \mathrm{c}$ & $0.053 \mathrm{~b}$ & $24.67 \mathrm{c}-\mathrm{f}$ & $1.0 \mathrm{c}$ & $0.720 \mathrm{c}$ & $0.527 \mathrm{~g}$ & $0.627 \mathrm{i}$ \\
\hline & 96 & $0.075 \mathrm{c}$ & $0.004 \mathrm{bc}$ & $27.00 \mathrm{~b}-\mathrm{d}$ & $1.0 \mathrm{c}$ & $0.770 \mathrm{c}$ & $0.787 \mathrm{e}$ & $0.873 \mathrm{~g}$ \\
\hline & 144 & $0.041 \mathrm{c}$ & $0.0125 \mathrm{bc}$ & $35.00 \mathrm{a}$ & $1.0 \mathrm{c}$ & $0.727 \mathrm{c}$ & $0.920 \mathrm{c}$ & $1.090 \mathrm{~d}$ \\
\hline & 192 & Zero c & Zero c & $36.67 \mathrm{a}$ & $2.00 \mathrm{~b}$ & $0.823 \mathrm{~b}$ & $0.905 \mathrm{c}$ & $1.247 \mathrm{~b}$ \\
\hline \multirow[t]{6}{*}{20} & control & Zero c & Zero c & $36.67 \mathrm{a}$ & $2.33 \mathrm{a}$ & $0.933 \mathrm{a}$ & $1.10 \mathrm{a}$ & $1.320 \mathrm{a}$ \\
\hline & Infection without spray & $0.725 \mathrm{c}$ & $0.20 \mathrm{a}$ & $21.67 \mathrm{ef}$ & $1.23 \mathrm{c}$ & $0.520 \mathrm{f}$ & $0.243 \mathrm{Ij}$ & 0.3971 \\
\hline & 48 & $0.289 \mathrm{~b}$ & $0.048 \mathrm{bc}$ & $21.00 \mathrm{ef}$ & $1.13 \mathrm{c}$ & $0.670 \mathrm{~d}$ & $0.483 \mathrm{~h}$ & $0.577 \mathrm{j}$ \\
\hline & 96 & $0.107 \mathrm{c}$ & $0.027 \mathrm{bc}$ & $26.00 \mathrm{c}-\mathrm{e}$ & $1.0 \mathrm{c}$ & $0.743 \mathrm{c}$ & $0.723 \mathrm{f}$ & $0.783 \mathrm{~h}$ \\
\hline & 144 & $0.063 \mathrm{c}$ & $0.004 \mathrm{bc}$ & $28.33 \mathrm{bc}$ & $1.0 \mathrm{c}$ & $0.663 \mathrm{c}$ & $0.877 \mathrm{~cd}$ & $0.987 \mathrm{f}$ \\
\hline & 192 & $0.011 \mathrm{c}$ & $0.004 \mathrm{bc}$ & $32.00 \mathrm{ab}$ & $1.0 \mathrm{c}$ & $0.770 \mathrm{c}$ & $0.970 \mathrm{~b}$ & $1.190 \mathrm{c}$ \\
\hline \multirow[t]{6}{*}{30} & Control & Zero c & Zero c & $36.67 \mathrm{a}$ & $2.33 \mathrm{a}$ & $0.933 \mathrm{a}$ & $1.10 \mathrm{a}$ & $1.320 \mathrm{a}$ \\
\hline & Infection without spray & $0.0725 \mathrm{a}$ & $0.200 \mathrm{a}$ & $22.33 \mathrm{~d}-\mathrm{f}$ & $1.23 \mathrm{c}$ & 0.550 ef & $0.223 \mathrm{j}$ & $0.333 \mathrm{~m}$ \\
\hline & 48 & $0.774 \mathrm{a}$ & $0.239 \mathrm{a}$ & $26.33 \mathrm{c}-\mathrm{e}$ & $1.0 \mathrm{c}$ & $0.650 \mathrm{~d}$ & $0.453 \mathrm{~h}$ & $0.563 \mathrm{j}$ \\
\hline & 96 & $0.098 \mathrm{c}$ & $0.026 \mathrm{bc}$ & $25.33 \mathrm{c}-\mathrm{f}$ & $1.0 \mathrm{c}$ & $0.727 \mathrm{c}$ & $0.683 \mathrm{f}$ & $0.750 \mathrm{~h}$ \\
\hline & 144 & $0.013 \mathrm{c}$ & $0.0036 \mathrm{bc}$ & $31.67 \mathrm{ab}$ & $1.0 \mathrm{c}$ & $0.673 \mathrm{~d}$ & $0.857 \mathrm{~d}$ & $0.887 \mathrm{~g}$ \\
\hline & 192 & $0.012 \mathrm{c}$ & $0.004 \mathrm{bc}$ & $34.00 \mathrm{a}$ & $1.0 \mathrm{c}$ & $0.830 \mathrm{~b}$ & $0.897 \mathrm{~cd}$ & $1.040 \mathrm{e}$ \\
\hline
\end{tabular}

Values withen dody of the table followed by the same letter are not significant different at $\mathrm{p}<0.05$ according to Duncan test . 


\title{
تأثير مبيد الكلايوفوسيت في الحامول (Cuscuta sp) النامي على محصول البرسيم (Trifolium alexandrinum $\mathrm{L}$ ).
}

\author{
قسم المحاصيل الزر اعية / كلية الزرباعة و الغابات/ جامعة المباد الموصل
}

\section{الخلاصة}

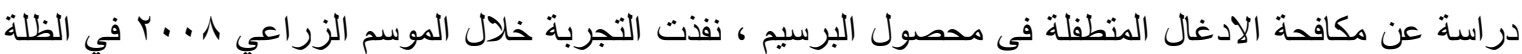

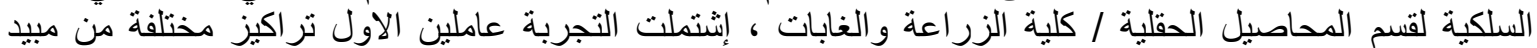

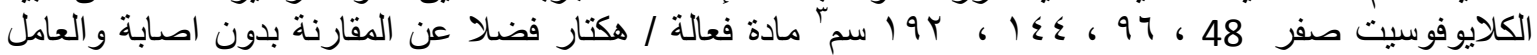

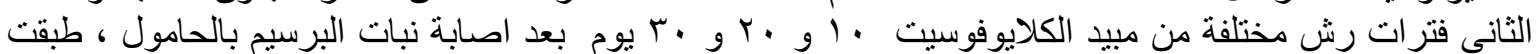

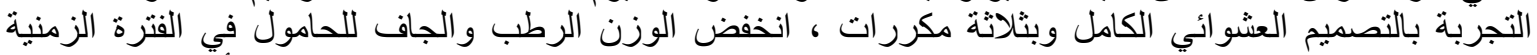

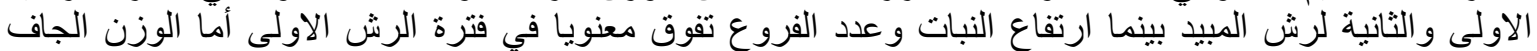

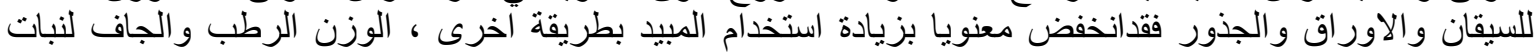

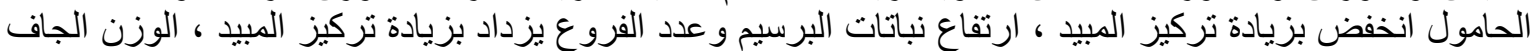

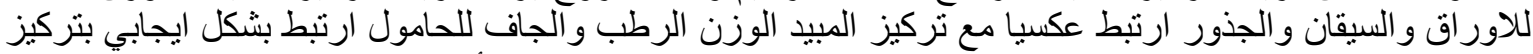

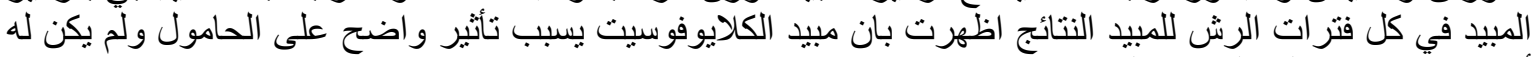

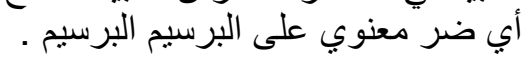

\section{References}

Abd El-Hamid , M.M. and S.M.Shebl.(2000).Weed control research. Section Field Crops Res . Institute, A.R.C.Giza, Egypt.

Abu-Irmaileh , B.E.and ,J.E Fucik.(1989) Using glyghosate to control eastern dodder on citrus in Jordan . HortScience 24,311-312.

Altekrette R.A, T.Y.Rezek, and , H.A Alromme . (1981) Forage Crops and Pasture . Mosul Univ .

Ashton,F.M.(1976) . Cuscuta spp. dodder . A literature review of its biology and control . Bull . Div. Agric. Scien.Univ.Cal.(1):22pp.

Dawson ,J.H.and A.R.Saghir (1983). Herbicides applied to dodder (Cuscuta spp) after attachment to alfalfa(Medicago sativa) Weed Science $31: 465-471$.

Fer , A.(1983) Investigation of a new strategy for dodder using systemic herbicides . results with labelled molecules in the laboratory (in French. In Compte Rendu de la 12e Conference du COLUMA1,pp.179-186.

Hacquet, J. ; R. DumontFer.; A.Cadot and Rousselot . 1983. Account of trials in 1982 and 1983 for dodder control in lucerne. $12^{\text {th }}$ Conference Columa, pp. 196-178.

Hassanein E.E. and , H.M. Ibrahim . (2000) . Weed Control Resaerch . Section , field crops Resaerch . Institute, A.R.C.Giza,Egypt .

Karapetyan , N .O.1972 . The effects of the depth and duration of burial of dodder seeds in the soil on the germination . Izvestiya- selskohozyaistvennykh-Nauk-Armyanskoissr..5,49-54.

Maddah, M.B.(1976). Prolonged emergence of dodder (Cuscuta approximate Bob.) in alfalfa . Iranian Jornal of plant Pathology . 12:3/4,29.

Moshalenko , G.P.and ,P.E Dement'ev, (1991) Control of Cuscuta species (in Russian) .zashchita Rastenii 4, 48-49.

Norris,R.F. 1973. Winter weed control in alfalfa- shattering the myth. Calif Weed Conc. $25^{\text {th }}$ Annual. Anatheim. (C.F. AL-Jubori, B.A and Al- Hasawy, K.S. 1982. Weeds and Weed Management.)

Saffour . K.(1999) La cuscute (Cuscuta spp) dans le Sais le pre-Rif : Importance enemis naturels . In Klein , O. \&Kroschel , J.(ed) :Rapport final d' activites duprojet supraregional Ecologie et gestion des plantes parasites 1992-1999 Description du projet, resume des activites, recommendations et liste de publications projet Supraregional Ecologie et Gestion des plantes parasites ,Fes , Maroc . 59-62. 